\title{
In vitro Evaluation of Botanicals against Colletotrichum capsici inciting Fruit Rot of Chilli
}

\author{
Chusa J. Sangma, Narola Pongener* and Valenta Kangjam
}

Department of Plant Pathology, School of Agricultural Sciences and Rural Development, Nagaland University, Medziphema Campus, Nagaland, India

*Corresponding author

Keywords

Fruit rot, Colletotrichum capsici, Botanicals, Inhibition,

Germination,

Vigour index

Article Info

Accepted:

07 September 2020

Available Online:

10 October 2020

\section{A B S T R A C T}

The anthracnose of chilli caused by Colletotrichum capsici, is a serious widespread disease in India and a limiting factor for profitable cultivation and seed production of chilli. Present experiment was aimed at studying the efficacy of various botanical extract on the mycelial growth, germination and seedling vigour of $C$. capsici. All the twenty botanicals at $10 \%$ concentration that were tested were found effective in inhibiting the mycelial growth of the pathogen with per cent inhibition ranging from 6.67 to $60.19 \%$. Among different botanicals tested, Aegle marmelos, Eucalyptus globules, Polyalthia longifolia, Allium sativum, Zingiber officinale, Allium cepa, Carica papaya and Curcuma longa were found superior as compared to other treatments and control. A. marmelos recorded the highest inhibition of $60.19 \%$ with a radial growth of $3.58 \mathrm{~cm}$. The least inhibition was recorded from Duranta repens (7.78\%) and Bougainvillea spectabilis $(6.67 \%)$ with a radial growth of 8.3 and $8.4 \mathrm{~cm}$. The most promising botanicals (eight) were selected for further evaluation on the seed germination and seedling vigour index. Maximum per cent seed germination and seedling vigour index was observed in seeds treated with extract of garlic with germination per cent of $94.67 \%$ and vigour index of 747.73. Among all treatments, maximum root/shoot length and vigour index was found by A. sativum and A. marmelos treated seeds.

\section{Introduction}

Chilli (Capsicum annuum L.) one of the most important commercial crop of India belongs to the Solanaceae family which represents a diverse plant group. Capsicum contains approximately 20-27 species, five of which are domesticated viz., $C$. annuum, $C$. baccatum, $C$. chinense, $C$. frutescens, and $C$. pubescens, and are cultivated in different parts of the world. Among the five species of cultivated Capsicum, $C$. annuum is one of the most common cultivated crops worldwide (Tong and Bosland, 1999) followed by $C$. frutescens (Bosland and Votava, 2003). It comprises numerous chemicals including steam-volatile oils, fatty oils, capsaicinoids, carotenoids, vitamins, protein, fibre and mineral elements (Bosland and Votava, 2003). The world area and production of chilli is around 1.5 million ha and 7 million tonnes, respectively (Rao, 2014). In Nagaland the 
area, production and productivity of green chilles is estimated at 5.82 thousand hectares, 41.90 thousand tonnes and 7.20 tonnes/hectare whereas that of dry chillies is estimated at 0.80 thousand 3 hectares, 1.00 thousand tonnes and 1.25 tonnes/hectares respectively (Anon, 2015). Chilli suffers from various diseases and chilli anthracnose is one of the most important among them. Anthracnose disease caused by the fungus Colletotricum capsici is the most destructive disease of chilli, which cause pre and post emergence damping off, leaf spots, premature fruit drop, mummification of unripe green fruits and fruit rot, which contribute 50-100\% loss in India (Amusa et al., 2004). Anthracnose causes the healthy green fruits and red ripe fruits lose $31 \%$ and $46 \%$ ascorbic acid after 14 days of pathogenesis (Ramesh, 2007) and 25\% loss of capsaicin content (Prasad et al., 2000). The above reasons prompted the present study to test the efficacy of botanicals in vitro.

\section{Materials and Methods}

Fruit rot caused by $C$. capsici and chilli fruit showing characteristic symptoms of the pathogen were collected and brought to the Department laboratory for isolation. The pathogen, $C$. capsici was isolated on Potato Dextrose Agar medium (PDA). The infected fruits were surface sterilized with $0.4 \%$ sodium hypochlorite for 2 minutes to remove the non-causal micro-organisms.

The specimen were then taken and cut into small bits through the infected spots and was transferred into Petri plates containing the medium and were incubated for 3 days until the mycelial growth was observed. Thereafter, the growing tips of the mycelia of the fungi were then transferred to PDA slants and incubated at $25 \pm 2{ }^{\circ} \mathrm{C}$ till conidial formation for obtaining pure cultures of the pathogen.

\section{Characteristics of the pathogen}

The pathogen obtained was studied based on colony characters and their morphological characters. The stock culture was maintained on PDA slants in the refrigerator at $5^{\circ} \mathrm{C}$.

The pathogen isolated was observed under the microscope for identification. Under observation, the characteristics of the pathogen were recorded as follows:

Conidia- The conidia were found to be falcate, fusiform, single celled and hyaline with a central oil globule.

Conidiophores- The conidiophores are hyaline to faintly brown, cylindrical in shape and either septate or aseptate.

Setae- The setae was observed to be dark brown in colour which are paler at the apex, rigid and tapering towards the apex.

Colour- The colour of the isolate in PDA medium was observed to be light grey to dark grey in colour.

Microsclerotia- The presence of small microsclerotia arranged in concentric rings in the colony was found to be irregular in shape under the microscope.

\section{Source of seed}

The seeds were of local variety obtained from the local market at Medziphema, Nagaland.

Composition of media used in the experiment

\section{Potato Dextrose Agar (PDA)}

Peeled potato $200 \mathrm{~g}$

Dextrose $20 \mathrm{~g}$

Agar-agar $20 \mathrm{~g}$

Distilled water $1000 \mathrm{ml}$ 


\section{Czapek Dox medium}

The formulation used as developed by Thom and Church (1926) is as follows:

Sucrose $30.0 \mathrm{~g}$

Sodium Nitrate $2.0 \mathrm{~g}$

Dipotassium Phosphate $1.0 \mathrm{~g}$

Magnesium Sulfate $0.5 \mathrm{~g}$

Potassium Chloride $0.5 \mathrm{~g}$

Ferrous Sulfate $0.01 \mathrm{mg}$

Agar-agar $15.0 \mathrm{~g}$

Distilled water $1000 \mathrm{ml}$

\section{Preparation of botanicals}

The plant parts (100g each) used were initially washed, air dried and individually crushed in mortar and pestle after which it was transferred into a conical flask. It was soaked in ethanol 95\%(100 ml) @ 1:1 w/v and was incubated at $60^{\circ} \mathrm{C}$ for $4-5$ days for the ethanol to evaporate It was taken out when the ethanol was evaporated and $100 \mathrm{ml}$ of sterile distilled water was added to the conical flask containing the extract. The macerate was then filtered through sterile Whattman filter paper No. 41 and the filtrates were considered as standard extract $(100 \%)$.

\section{Evaluation of botanicals against Colletotrichum capsici}

The efficacy of botanical extracts in relation to the growth of pathogens was determined by the method of Schmitz (1930). An appropriate amount of leaf extract was added to sterilize warm Czapek Dox medium and thoroughly mixed just before plating to form $10 \%$ concentration.

Twenty $\mathrm{ml}$ of this mixture was immediately poured into a sterilized Petri plate of $90 \mathrm{~mm}$ diameter in three replications and allowed to solidify. A $10 \mathrm{~mm}$ culture disc of $C$. capsici from PDA culture was removed and placed onto the centre of the medium. The plates were incubated at $28 \pm 2^{\circ} \mathrm{C}$ for 10 days. Czapek Dox medium without plant extract served as the control.

The radial growth of the colony was measured on the 10th day when the mycelium fully covered the control plates. The per cent inhibition of the growth was calculated. The per cent inhibition of the growth of the colony was calculated as per Vincent (1947) and expressed by using the formula:

$$
\text { Per cent inhibition }=\frac{C-T}{C} \times 100
$$

Where,

$\mathrm{C}=$ Diameter of growth in control

$\mathrm{T}=$ Diameter of growth in the treatment

Evaluation of botanicals on seed germination and seedling vigour index

The test was carried out following the method of international rules for seed health testing (ISTA, 1996). Based on the above experiment, selected botanicals which showed the maximum radial inhibition on the test pathogen were used. The seeds were soaked in the selected botanicals at the required concentration (10\%) for 1 hour. For control, the seeds were soaked in distilled water.

Three pieces of blotting paper of $90 \mathrm{~mm}$ size were moistened with distilled water and placed in $90 \mathrm{~mm}$ sterilized Petri dishes after draining excess water. After 1 hour, the treated seeds were placed on the Petri dishes at the rate of 25 seeds per plate at equal distance in each Petri dish. The plates were incubated at room temperature $\left(28^{\circ} \mathrm{C}\right)$ under alternate cycles of 12 hours NUV light and darkness. Data was recorded on seedling germination, root length, shoot length and total length at 15 DAS. 
The germinated seeds were counted and the percent germination was computed by using the formula:

Per cent germination $=\underline{\text { Number of germinated seeds }} \times 100$ Number of seeds sown

Length of shoot was measured from the collar region to the tip of the longest leaf and expressed as $\mathrm{cm}$. Root length of the seedlings was measured from the base of the stem to the tip of the longest root and expressed as $\mathrm{cm}$. the vigour index was calculated by using the formula:

Vigour Index $=($ Mean root length + Mean shoot length) $\times$ Per cent germination

\section{Experimental design}

The experiment was done in a Completely Randomized Design (CRD) and each treatment was replicated three times. The treatment combination for evaluation of botanicals (Table 1) on radial growth of $C$. capsici was laid as follows:

T1: C. capsici + Bael

T2: $C$. capsici + Blue gum

T3: C. capsici + Bougainvillea

T4: $C$. capsici + False ashoka

T5: C. capsici + Garlic

T6: $C$. capsici + Ginger

T7: $C$. capsici + Golden dewdrop

T8: $C$. capsici + Hibiscus

T9: C. capsici + Holy basil

T10: $C$. capsici + Neem

T11: $C$. capsici + Onion

T12: $C$. capsici + Papaya

T13: C. capsici + Periwinkle

T14: C. capsici + Satavari

T15: C. capsici + Shrub verbena

T16: C. capsici + Sweet basil

T17: C. capsici + Thai nightshade

T18: C. capsici + Turmeric

T19: . capsici + Veld grape
T20: $C$. capsici + Yellow nightshade

T0: C. capsici (Control)

The treatment combination for evaluation of botanicals on seed germination and seedling vigour index are as follows:

T1: Seed treatment with bael

T2: Seed treatment with blue gum

T3: Seed treatment with false ashoka

T4: Seed treatment with garlic

T5: Seed treatment with ginger

T6: Seed treatment with onion

T7: Seed treatment with papaya

T8: Seed treatment with turmeric

T0: Seed treatment with distilled water (Control)

\section{Results and Discussion}

\section{Evaluation of botanicals on Colletotrichum capsici}

The selected twenty plants were used for preliminary screening at $10 \%$ concentration each using the method followed by Schimtz (1930). The average growth of the pathogen was recorded on the $10^{\text {th }}$ day when the mycelium fully covered the control plates.

Effect of the treatments with botanicals on the radial growth and per cent inhibition of the isolated test pathogen $C$. capsici were recorded and are presented in Table 2. The results revealed that all the treatments inhibited the radial growth of the pathogen ranging from $60.19 \%$ to $6.67 \%$ compared to the non-treated control $(00.00 \%)$. Amongst the botanicals that were tested, $\mathrm{T}_{1}$ (bael) was found most effective against $C$. capsici which showed a radial growth of $3.58 \mathrm{~cm}$ and per cent inhibition of $60.19 \%$. The findings are in accordance with the report of Anand and Bhaskaran (2009), who reported that the leaf extracts of Abrus precatorius and Aegle marmelos, demonstrated the highest inhibition 
of growth against two pathogens studied viz., C. capsici and Alternaria alternata. The reason of bael being the most effective treatment in the conducted experiment may be due to the presence of an essential oil terpenoid which is known to be effective against fungi (Gurjar et al., 2012).

These treatments were further followed by $T_{5}$ (garlic) showing a radial growth of $4.4 \mathrm{~cm}$ which was statistically at par with $T_{18}$ (turmeric) with a mean colony diameter of 4.4 $\mathrm{cm}$ and an inhibition of 51.30 and $50.93 \%$. The observations are in tune with the works of Ushakiran et al., (2006) who also reported that Allium sativum showed a radial growth of $4.5 \mathrm{~cm}$ with an inhibition of $50.33 \%$ at $10 \%$ concentration and a radial growth of $5.1 \mathrm{~cm}$ and inhibition of $43.67 \%$ at $5 \%$ concentration, respectively. The antifungal activity of garlic against the pathogen has also been reported by other researchers such as Rajamanickam et al., (2012) and Sundramoorthy et al., (2014). The efficacy of turmeric against $C$. capsici has also been previously reported by Anand and Bhaskaran (2009), Jagtap et al., (2013) and Rahman et al., (2011) who reported that Curcuma longa (leaf) also possesses high ability to inhibit conidial germination and germ tube formation of $C$. capsici. The antimicrobial activity of garlic and turmeric is due to the presence of an allicin, a sulfoxide and curcumin which is a terpenoid known to be effective against fungi, bacteria and protozoa (Gurjar, 2012). Singh et al., (1990) also reported that a compound ajoene, derived from garlic inhibited Colletotrichum spp. Among the botanicals evaluated, golden dewdrop (T7) and bougainvillea (T3) showed the least effectiveness against the studied pathogen with a radial growth of $8.3 \mathrm{~cm}$ and $8.4 \mathrm{~cm}$ with minimum inhibition of $7.78 \%$ and $6.67 \%$.

Table.1 List of the botanicals used in the experiment

\begin{tabular}{|l|l|l|l|}
\hline Sl. No. & Common name & Scientific name & Parts used \\
\hline 1. & Bael & Aegle marmelos & Leaves \\
\hline 2. & Blue gum & Eucalyptus globules & Leaves \\
\hline 3. & Bougainvillea & Bougainvillea spectabilis & Leaves \\
\hline 4. & False ashoka & Polyalthia longifolia & Leaves \\
\hline 5. & Garlic & Allium sativum & Cloves \\
\hline 6. & Ginger & Zingiber officinale & Rhizome \\
\hline 7. & Golden dewdrop & Duranta repens & Leaves \\
\hline 8. & Hibiscus & Hibiscus rosa sinensis & Leaves \\
\hline 9. & Holy basil & Ocimum sanctum & Bulb \\
\hline 10. & Neem & Azadirachta indica & Leaves \\
\hline 11. & Onion & Allium cepa & Bulb \\
\hline 12. & Papaya & Carica papaya & Leaves \\
\hline 13. & Periwinkle & Catheranthus roseus & Leaves \\
\hline 14. & Satavari & Asparagus racemosus & Leaves \\
\hline 15. & Shrub verbena & Lantana camara & Leaves \\
\hline 16. & Sweet basil & Ocimum basilicum & Leaves \\
\hline 17. & Thai nightshade & Solanum trilobatum & Leaves \\
\hline 18. & Turmeric & Curcuma longa & Rhizome \\
\hline 19. & Veld grape & Cissus quadrangularis & Whole \\
\hline 20. & Yellow nightshade & Solanum xanthocarpum & Leaves \\
\hline & & & \\
\hline
\end{tabular}


Table.2 Evaluation of botanicals against Colletotrichum capsici

\begin{tabular}{|l|l|c|c|}
\hline Treatment & Botanicals @ 10\% & $\begin{array}{c}\text { Mean colony } \\
\text { diameter } \mathbf{( c m )}\end{array}$ & Per cent inhibiton \\
\hline $\mathrm{T}_{1}$ & Bael & 3.6 & $60.19(50.88)$ \\
\hline $\mathrm{T}_{2}$ & Blue gum & 5.8 & $35.74(36.72)$ \\
\hline $\mathrm{T}_{3}$ & Bougainvillea & 8.4 & $6.67(14.94)$ \\
\hline $\mathrm{T}_{4}$ & False ashoka & 5.4 & $39.81(39.12)$ \\
\hline $\mathrm{T}_{5}$ & Garlic & 4.4 & $51.30(45.74)$ \\
\hline $\mathrm{T}_{6}$ & Ginger & 5.7 & $36.67(37.27)$ \\
\hline $\mathrm{T}_{7}$ & Golden dewdrop & 8.3 & $7.78(16.20)$ \\
\hline $\mathrm{T}_{8}$ & Hibiscus & 5.8 & $35.37(36.50)$ \\
\hline $\mathrm{T}_{9}$ & Holy basil & 7.9 & $12.78(20.94)$ \\
\hline $\mathrm{T}_{10}$ & Neem & 6.4 & $28.70(32.39)$ \\
\hline $\mathrm{T}_{11}$ & Onion & 5.5 & $39.07(38.69)$ \\
\hline $\mathrm{T}_{12}$ & Papaya & 5.1 & $43.70(41.38)$ \\
\hline $\mathrm{T}_{13}$ & Periwinkle & 7.4 & $17.41(24.66)$ \\
\hline $\mathrm{T}_{14}$ & Satavari & 8.3 & $8.15(16.58)$ \\
\hline $\mathrm{T}_{15}$ & Shrub verbena & 6.3 & $30.19(33.33)$ \\
\hline $\mathrm{T}_{16}$ & Sweet basil & 7.4 & $18.15(25.21)$ \\
\hline $\mathrm{T}_{17}$ & Thai nightshade & 7.4 & $17.41(24.66)$ \\
\hline $\mathrm{T}_{18}$ & Turmeric & 4.4 & $50.93(45.53)$ \\
\hline $\mathrm{T}_{19}$ & Veld grape & 6.1 & $24.44(29.63)$ \\
\hline $\mathrm{T}_{20}$ & Yellow nightshade & 7.4 & $18.15(25.21)$ \\
\hline $\mathrm{T}_{0}$ & Control & 9 & 00.00 \\
\hline $\mathbf{S .} \mathbf{E m} \pm$ & & 0.03 & 0.25 \\
\hline $\mathbf{C D}$ & & 0.09 & 0.72 \\
\hline $\mathbf{p}=\mathbf{0 . 0 5})$ & & & \\
\hline & & & \\
\hline
\end{tabular}

Note: Figure in the table are mean values and those in parenthesis are angular transformed value

Table.3 Effect of botanicals on seed germination and seedling vigour

\begin{tabular}{|l|l|c|c|c|c|}
\hline Treatment & $\begin{array}{c}\text { Plant } \\
\text { extracts } \\
(\mathbf{1 0 \%})\end{array}$ & $\begin{array}{c}\text { Percent } \\
\text { germination } \\
(\mathbf{\%})\end{array}$ & $\begin{array}{c}\text { Root } \\
\text { length } \\
(\mathbf{c m})\end{array}$ & $\begin{array}{c}\text { Shoot } \\
\text { length } \\
(\mathbf{c m})\end{array}$ & Vigour index \\
\hline $\mathrm{T}_{1}$ & Bael & $92.00(73.92)$ & 5.6 & 2.5 & 738.67 \\
\hline $\mathrm{T}_{2}$ & Blue gum & $93.33(75.55)$ & 4.8 & 2.4 & 672.53 \\
\hline $\mathrm{T}_{3}$ & False ashoka & $88.00(69.73)$ & 4.6 & 2.3 & 607.20 \\
\hline $\mathrm{T}_{4}$ & Garlic & $94.67(76.83)$ & 5.4 & 2.5 & 747.73 \\
\hline $\mathrm{T}_{5}$ & Ginger & $90.67(72.29)$ & 4.7 & 2.4 & 646.53 \\
\hline $\mathrm{T}_{6}$ & Onion & $85.33(67.81)$ & 4.4 & 2.2 & 558.93 \\
\hline $\mathrm{T}_{7}$ & Papaya & $90.67(72.82)$ & 4.5 & 1.9 & 578.00 \\
\hline $\mathrm{T}_{8}$ & Turmeric & $89.33(71.54)$ & 4.7 & 2.4 & 635.07 \\
\hline $\mathrm{T}_{0}$ & Control & $78.67(62.53)$ & 4.0 & 1.5 & 430.40 \\
\hline $\mathbf{S . ~ E m} \pm$ & & 1.62 & 0.11 & 0.02 & 15.91 \\
\hline $\mathbf{C D}(\mathbf{p}=\mathbf{0 . 0 5})$ & & 4.61 & 0.30 & 0.07 & 45.40 \\
\hline
\end{tabular}

Note: Figure in the table are mean values and those in parenthesis are angular transformed value 
Inhibition of plant pathogenic fungi by many antifungal compounds of plant origin has been supported by previous works of Hemmanavar (2008), Ranasingh et al., (2011), Geat (2014), and Harsha et al., (2004).

\section{Evaluation of botanicals on seed germination and seedling vigour index}

In the present investigation, eight most promising botanicals i.e. A. marmelos, Eucalyptus globules, Polyalthia longifolia, A. sativum, Zingiber officinale, A. cepa, Carica papaya, and $C$. longa, were selected based on their effectiveness in inhibiting the mycelial growth of $C$. capsici and were further evaluated for its effect on germination and seedling vigour index. The results on the effect of botanicals on germination and seedling vigour index are presented in Table 3. The results revealed that the highest germination was obtained from T4 (garlic) with a germination of $94.67 \%$. This was at par with T2 (blue gum), T1 (bael), T7 (papaya), T5 (ginger), T8 (turmeric) and T3 (false ashoka) showing a germination percentage of $93.33,92.00,90.67,90.67,89.33,88.00$ respectively. Among the botanicals T6 (onion) with $85.33 \%$ recorded the lowest germination. T0 (control) recorded the least germination of $78.67 \%$ amongst all the treatments. The results are similar to those found by Sundramoorthy et al., (2014) who reported that among the various plant products tested, A. sativum followed by $E$. globules showed maximum germination and seedling growth amongst the botanicals that were tested. Islam et al., (2010) also observed in his experiment that seed treatment with garlic enhanced seed germination. These findings are also similar to the work done by Choudhary et al., (2013) who reported a maximum per cent seed germination (94\%) as a result of seed treatment by safeda ( $E$. tereticornis). Plant extracts are known to effect seed germination and initial seedling growth parameters (Sahoo et al., 2015).

In the conducted experiment it has been recorded that most of the botanicals increased the germination of the seeds as compared to control which showed the least germination percentage. The reason for increase in germination by use of botanical extract presumed that these botanicals contain some of the micronutrients which are conducive for seed invigoration as reported by Sasthri and Srimathi (2010).

Seed soaking with botanical extract also had a significant effect in root length of chilli. The highest root length was recorded from $\mathrm{T}_{1}$ (bael) with $5.6 \mathrm{~cm}$ which was at par with $\mathrm{T}_{4}$ (garlic) showing $5.4 \mathrm{~cm}$. This was followed by $\mathrm{T}_{2}$ (blue gum) which was found to be at par with $\mathrm{T}_{5}$ (ginger), $\mathrm{T}_{8}$ (turmeric), $\mathrm{T}_{3}$ (false ashoka), $\mathrm{T}_{7}$ (papaya) and $\mathrm{T}_{6}$ (onion) each showing a root length of 4.8, 4.7, 4.7, 4.6, 4.5 and $4.4 \mathrm{~cm}$. The lowest root length of $4.0 \mathrm{~cm}$ was recorded in T0 (control), which might be due to low availability of nutrients in water. The increase in the root length of chilli seedlings might be due to presence of phenols in the botanical extracts which could have promoted the root length.

In the present study the longest shoot length was obtained from $\mathrm{T}_{4}$ (garlic) with $2.5 \mathrm{~cm}$ which was at par with $\mathrm{T}_{1}$ (bael). This was followed by $\mathrm{T}_{2}$ (blue gum) which was found to be at par with $\mathrm{T}_{5}$ (ginger) and $\mathrm{T}_{8}$ (turmeric) each showing a shoot length of $2.4 \mathrm{~cm}$. These were further followed by $\mathrm{T}_{3}$ (false ashoka), $\mathrm{T}_{6}$ (onion) and $\mathrm{T}_{7}$ (papaya) with 2.3, 2.2 and 1.9 $\mathrm{cm}$. The shortest shoot length was observed in T9 (control) with $1.5 \mathrm{~cm}$.

The increased shoot length due to seed treatment with botanical extracts may be attributed to cell wall extension and increased metabolic activities at low water potential, as 
in matripriming as reported by Afzal et al., (2002). Botanicals contain various growth promoting substance and nutrients (Anon, 2002) which could support better seedling performance.

Perusal of the data (Table 3) clearly proves that amongst the seed treated with botanicals @ $10 \%, \mathrm{~T}_{4}$ (garlic) gave the highest vigour index at 747.73 which was at par with $\mathrm{T}_{1}$ (bael) showing a vigour index of 738.67. This was followed by $T_{2}$ (blue gum) which was at par with $\mathrm{T}_{5}$ (ginger), $\mathrm{T}_{8}$ (turmeric), $\mathrm{T}_{3}$ (false ashoka), $\mathrm{T}_{7}$ (papaya) and $\mathrm{T}_{6}$ (onion) each with a vigour index of $672.53,646.53,635.07$, $607.20,578.00$ and 558.93 respectively. Among the treatments $\mathrm{T}_{0}$ (control) recorded the lowest vigour index of 430.40 .

Similar findings were reported by Sundramoorthy et al., (2014) who also observed that treatment of chilli seeds with garlic recorded the maximum vigour index. The result are also in accordance with the works of Choudhary et al., (2013) who observed a seedling vigour index of 540.05 by treatment of seeds with safeda leaves extract (E. terticornis). Similar results in increasing per cent germination and enhancing growth characters of chilli seedlings by use of different plant extracts were also reported by Sahoo et al., (2015), Alam et al., (2014), Kumar et al., (2014) and Islam and Faruq (2012)

\section{References}

Afzal, I., Ahmed, S. M. A., Ahmed, N., Cheema, M. A., Warraich, E. A. and Khaliq, A. 2002. Effect of priming and growth regulator treatment on emergence seedling growth of hybrid maize. International Journal of Agriculture and Biology. 4: 303-306.

Alam, M. Z., Hamim, I., Ali, M. A. and Ashrafuzzaman, M. 2014. Effect of seed treatment on Ssedling health of chili. Journal of Environmental Science and Natural Resources. 7(1): 177-181.

Amusa, N. A., Kehinde, I. A. and Adegbite, A. A. 2004. Pepper fruit anthracnose in the humid forest region of South Western Nigeria. Nutrition and Food Science. 34: 130-134.

Anand, T. and Bhaskaran, R. 2009. Exploitation of plant products and bioagents for ecofriendly management of chilli fruit rot disease. Journal of Plant Protection Research. 49(2):195203.

Anonymous. 2002. All India co-ordinated national project (crops). Annual report. Indian Agriculture Research Institute, New Delhi.

Anonymous. 2015. Horticulture statistics at a glance 2015. Horticulture Statistics Division, Ministry.

Bosland, P. W. and Votava, E. J. 2003. Peppers: Vegetable and Spice Capsicums. CAB International, England. Pp. 233.

Choudhary, C. S., Jain, S. C., Kumar, R. and Choudhary, J. P. 2013. Efficacy of different fungicides, biocides and botanical extract seed treatment for controlling seed-borne Colletotrichum sp. in chilli (Capsicum annuиm L.). The Bioscan. 8(1): 123-126.

Gurjar, M. S., Ali, S., Akhtar, Masood and Singh, K. S. 2012. Efficacy of plant extracts in plant disease management. Agricultural Sciences. 3: 425-433.

Islam, M. T. and Faruq, A. N. 2012. Effect of some medicinal plant extracts of damping-off disease of winter vegetable. World Applied Sciences. 17(11): 1498-1503.

Islam, M. M., Islam, M. R., Aminuzzaman, Faruq and Siddiquee, T. A. 2010. Efficacy of fungicides and plant extracts on management of 
anthracnose (Colletotrichum capsici) of Chilli (Capsicum annuum L.). The Agriculturists. 8(1): 1-9.

ISTA. 1996. International rules of seed testing association. In. Proceedings of the International Seed Testing Association. pp 19-44.

Jagtap, G. P., Mali, A. K. and Dey, U. 2013. Bioefficacy of fungicides, bio-control agents and botanicals against leaf spot of turmeric incited by Colletortrichum capsici. African Journal of Microbiology Research. 7(18): 18651873.

Kumar, S. R., Kumar, M. and Muthukrishnan, R. 2014. Studies on seed quality enhancement with botanicals in tomato and chillies. Research Journal of Agricultural Sciences. 5(5): 852 855.

Prasad, B. K., Sahu, D. R. and Kumar, N. N. 2000. Decay of chilli fruits in India during storage. Indian Phytopathology. 53: 42-44.

Rahman, D. M. M., Khan, A. A. and Mian, I. H. 2005. Control of seed borne fungi of chilli by seed treatment with fungicides and botanicals. Journal of Plant Pathology. 21(1/2): 63-66.

Rajamanickam, S., Sethuraman, K. and Sudasakthi, A. 2012. Exploitation of phytochemicals from plant extracts and its effect on growth of Colletotrichum capsici (Syd.) Butler and Bisby causing anthracnose of chilli (Capsicum annum L.). Plant Pathology Journal. 11(3): 87-92.

Rao, G. 2014. Crop reports - chilli and turmeric. World Spice Congress. pp
38.

Sahoo, U. K., Jeeceelee, L., Lallinrawna, S. and Muthukumaran, R. B. 2015. Effect of Citrus reticulata blanco leaf extract on seed germination and initial seedling growth parameters of five home garden food crops. Journal of Experimental Biology and Agricultural Sciences. 3(6): 517-528.

Sasthri, G. and Srimathi, P. 2010. Effect of organic and inorganic and priming treatment on production of quality seed cowpea. Green Farming. 1(4): 366-368.

Schmitz, H. 1930. Poisoned Food Technique. Industrial and Engineering Chemistry Analyst. 2: 361-363.

Sundaramoorthy, S., Usharani, S. and George, A P. 2014. Antifungal activity of plant products for the management of fruit rot of infection in chillies. Plant Pathology Journal. 13(2): 87-99.

Thom, C. and Church, M. B. 1926. The Aspergilli. Williams and Wilkins, Baltimore, MD.

Tong, N. and Bosland, P. W. 1999. Capsicum tovarii, a new member of the Capsicum complex. Euphytica. 109(2): 71-72.

Ushakiran, L., Chhetri, G. K. N. and Singh, N. I. 2006. Fruit rot diseases of chilli and their management in agro-climatic conditions of Manipur. Journal of Mycopathological Research. 44(2): 257-262.

Vincent, J. M. 1947. Distortion of fungal hyphae in the presence of certain inhibitors. Nature. 159: 850.

\section{How to cite this article:}

Chusa J. Sangma, Narola Pongener and Valenta Kangjam. 2020. In vitro Evaluation of Botanicals against Colletotrichum capsici Inciting Fruit Rot of Chilli. Int.J.Curr.Microbiol.App.Sci. 9(10): 515-523. doi: https://doi.org/10.20546/ijcmas.2020.910.062 